\title{
NEW TENTHREDINIDA.
}

BY ALEX. D. MACGILLIVRAY, ITHACA, N. Y,

Periclista, Knw.-This name was proposed by Knonow in his monograph of the European Blenocampids, published in the "Winer Ent. Zeit.," V. 1886, 186, for those species having the lanceolate cell petiolate, the eyes more or less remote from the bases of the mandibles, and the posterior wings with the outer cells closed by a marginal vein. This name had already been used by Forester, 1869 , for a genus of Cynipidæ, and I therefore propose the name Mogerus ( $\mu \circ \gamma \epsilon$ ós) to take its place.

Blennocampa bipartita, Cress.-From an examination of a type specimen of this species, received from the American Entomological Society, I find that this species should be referred to the genus Mogerus.

Mogerus emarginatus, n. sp. o.--Black, with the following parts luteous : the labrum, the femora, the tibiæ, the base of the tarsi, and the apex of the first, second, third and fourth abdominal segments indistinctly so; the collar and the tegulæ, white; the clypeus, angularly emarginate; the antennæ, thickened at base, especially the third and the fourth segments, the third segments about one-fourth longer than the fourth; the wings hyaline; the veins brown; the costa and the stigma luteous; the anterior ocellus in a basin which connects with a transverse sinus which is caudad of the posterior ocelli. Length, $6 \mathrm{~mm}$.

Habitat-Boston, Massachusetts. One specimen. This is the species and specimen referred to by Mr. Harrison $G$. Dyar in the CAN. ENT., XXVI., I 894, I 85, as Blennocampa bipartita, where a description of the larvæ has been published.

Selandria foridana, n. sp. o.-Black, with the following parts yellow: the clypeus (the labrum is fuscous), the tegulæ, a line on the collar, a spot on the mesopleuræ, the legs, including the coxæ, except the middle and posterior tarsi, the caudal margin of the ventral abdominal segments, and the entire apical segment; the clypeus truncate; the labrum rounded; the antennæ slightly thickened in the middle, the third segments one-third longer than the fourth; the wings blackish-fuscous, paler at apex; the veins, including the costa and the stigma, black; the body shining, impunctured; the lanceolate cell without a cross-vein, open at the shoulder; the posterior wings with two middle cells. Length, 4. $5 \mathrm{~mm}$.

Habitat-Ormond, Florida. 
A single specimen received from Mrs. Annie Trumbull Slosson. Readily separated from the described American species by the colour of the pleuræ.

Tenthredo bilineatus, n. sp. \%.-Black, with the following parts yellow: the clypeus, the labrtim, the mandibles except at apex, a spot on the front beneath the antenne, an ovate spot on the antennal ridges above the base of each antenna, the lower half of the cheeks, an elongate mark on the inner margin of the eye (this mark is half as long as the inner margin of the eye, reaching the meso-caudal angles of the eye, obliquely truncated in front, roundly emarginate on its mesal side, extending slightly beyoud the caudal margin of the eye, a rine spur extending from the middle of its caudal margin to an elongate, quadrangular spot along the latero-caudal margin of the head, sub-interrupted from the mark on the cheeks, not extending mesad beyond the mesal margin of the spot or the inner margin of the eye), a small spot on the vertex, in a line with the spots on the latero-caudal margin of the head and caudad of the ocelli, the tegulæ, the collar, two lines on the mesonotum, converging behind, a broad line from the scutellum to the base of the anterior wings, the cenchri, a small triangular spot on the cephalo-dorsal corner of the mesopleuræ, a spot above the posterior coxæ, the basal membrane, two large spots on the sides of the basal plates, the trochanters, the bases of the femora, the front tibiæ and tarsi, and the middle tibiæ slightly beneath; the following parts rufous: the first segments of the antennx entirely and the second and third on the inner side, the front and middle femora, the tibix above, the posterior femora beneath at apex, the posterior tibix, the middle and posterior tarsi, the venter, a narrow margin to the tergal segments one to three, and the tergal segments beyond the third; the third segments of the antennw one-third longer than the fourth; the clypeus emarginate; the wings hyaline, slightly yellowish; the veins black; the costa and the base of the stigma luteous. Length. $6 \mathrm{~mm}$.

Habitat-Ithaca, New York.

This species will be readily recognized by the markings on the head and mesonotum and the colour of the basal segments of the antennæ and the apex of the abdomen.

Tenthredo pallipunctus, n. sp. o.-Black, with the following parts yellow: the clypeus, the labrum, the mandibles except at apex, the lower part of the cheeks, a line on the collar, a spot above the posterior 
coxæ, the anterior legs, including the coxæ, beneath, and the middle tibia beneath (the middle femora have blotches of yellow beneath, so that specimens will probably be found having the femora yellow beneath); the third segments of the antenne one-third longer than the fourth; the clypeus emarginate; the wings hyaline, slightly fuscous; the veins, including the costa and the stigma, brownish. Length, I I $\mathrm{mm}$.

Habitat-Colorado. Mr. Carl F. Barker, collector.

This species is related to flavonarginis, from which it differs in having the tegula and basal plates black.

Tenthredo rufostigmus, n. sp. o.-Black, with the following parts yellow : the clypeus, the labrum, the mandibles except at apex, the lower half of the cheeks, the tegulæ, an abbreviated line on the caudal part of the pleuræ, a spot above the posterior coxæ, the front and middle coxæ except above, the posterior cox: at side, the front legs, beyond the coxæ, beneath, and the middle trochanters and femora beneath; the following prarts rufous: the middle tibiæ beneath, the middle tarsi, the posterior femora beneath, the posterior tibiæ and tarsi, and the abdomen, including the venter, beyond the basal plates except a spot on the base of the first tergal segment; the third segments of the antennæ one-fourth longer than the fourth; the clypeus squarely emarginate; the wings slightly infuscated; veins black; the costa and the stigma rufous. Length, Io $\mathrm{mm}$.

Habitat-Craig's Mt., Idaho. Prof. J. M. Aldrich, collector.

This species is related to discrepans, from which it differs in having the posterior femora rufous with a black line above.

Tenthredo atravenus, $\mathrm{n}$. sp. A.-Black, with the following parts rufous : the legs beyond the trochanters except a spot on the bases of the femora above (the posterior tarsi are yellowish), the apex of the second abdominal segment, the third, fourth, and fifth abdominal segments entirely, and the base of the sixth abdominal segment; the third segments of the antennæ one-half longer than the fourth, the clypeus truncate; the labrum rounded, yellowish-fuscous at sides; the wings slightly clouded, more pronounced on the apical half; the veins black; the costa rufous ; the stigma yellow, fuscous at base. Length, 10 $\mathrm{mm}$.

Habitat-Juliaetta, Idaho. Prof. J. M. Aldrich, collector.

This species is related to sectilis, from which it differs in having no pale spot above the posterior coxa.

Tenthredo terminutus, n. sp. \%.-Black, with the following parts yellow : the clypeus, the labrum, the mandibles except at apex, a spot on 
the cheeks, the tegulæ, the latero-dorsal angles of the pronotum, a spot above the posterior coxa, a spot on the sides of the basal plates, a fine line on the apical margin of the basal plates and the first and second abdominal segments, the front and middle legs, including the coxæ, beneath, the extreme apices of the posterior coxæ, and the posterior trochanters beneath; the following parts rufous: the posterior legs beneath beyond the trochanters, the tergal segments beyond the second, the sides of the third and fourth abdominal segments, and the ventral segments beyond the fifth, including the guides of the ovipositor; the clypeus squarely emarginate; the third segments of the antennæ onethird longer than the fourth; the wings subinfuscated; the costa and the base of the stigma rufous; the veins black. Length, $\mathrm{r} 2 \mathrm{~mm}$.

Habitat-Colorado. Mr. Carl F. Barker, collector.

This species is related to nigricoxus and bella; from the former it differs in not having the pale spot above the posterior coxæ wanting, and from the latter in having a black line above on all the legs.

Tenthredo cequalis, n. sp. $q$.-Black, with the following parts yellow: the clypeus, the labrum, the mandibles except at apex, a spot on the cheeks, the tegulæ, a line on the collar, a spot above the posterior coxæ, the anterior tibix beneath (the anterior femora are paler beneath; probably specimens will be found in which they are yellow beneath), and the anterior tarsi ; the following parts rufous: the femora, the middle and posterior tibix and tarsi (the anterior tibix have a fine black line above), a spot on the middle of the second and third tergal segments, larger on the third, the tergal segments beyond the third, and the ventral segments beyond the fifth except the ventral margin of the ovipositor ; the clypeus squarely emarginate; the third segments of the antennæ twice the length of the fourth; the wings hyaline, the veins black; the costa and the stigmaa at base luteous. Length, $5 \mathrm{~mm}$.

Habitat-Colorado. Mir. Carl F. Barker, collector.

This species is related to lunatus and olivatipes; it differs from the former in having a pale spot above the posterior coxæ, and from the latter in having the scutellum black and the legs rufous.

Tenthredo ventricus, $\mathrm{n}$. sp. o.-Black, with the following parts yellow : the clypeus, the labrum, the mandibles except at apex, the front beneath the antennæ, the cheeks, a fine line on the collar, a spot above the anterior coxæ, a spot above the posterior coxæ, and a spot on the sides of the basal plates; the following parts rufous: a fine line on the 
inner margins of the eyes, the tegulæ, the prosternum, the mesosternum, and the mesopleuræ, the legs, including the coxæ, except a black line on the coxæ and trochanters and femora above (the front and the middle legs are somewhat yellowish beneath), and the abdomen beyond the middle of the first segment; the clypeus squarely emarginate; the third segments of the antennæe one-third longer than the fourth; the wings hyaline; the veins brownish; the costa and the stigma luteous. Length, I I $\mathrm{mm}$.

Habitat-Colorado. Mr. Carl F. Baker, collector.

This species is related to rubelloides and hyalinus; it is separated from the former by having the tibiæ entirely pale, and from the latter by the rufous mesopleuræ and mesosternum and the squarely emarginate clypeus.

Macrophya pulchella alba, n. var. \&.-Black, with the following parts yellowish-white: the clypeus, the labrum, the mandibles except at apex, a triangular spot on the collar, the tegulæ, a circular spot on the pleuræ, the basal plates, the scutellum, the postscutellum, the front and middle legs, including the coxæ, except a ring on the apex of the tibiæ and the apices of the apical segments of the tarsi, the posterior coxæ and trochanters, the basal half of the posterior femora, and the tibie except a ring at the base and apex. Length, $8 \mathrm{~mm}$.

Habitat - Indiana (Baker), Pennsylvania and Illinois (Nason), and New York.

Macrophya punctata, n. sp. q.- Black, with the following parts white: the clypeus, the labrum, a spot on the bases of the mandibles, two spots on the caudal margin of the vertex, a narrow line on the collar, the tegulæa at base, the anterior coxæ beneath, the apices and a line on the side of the middle coxæ, a large spot on the sides of the posterior coxæ, the trochanters, the front femora, tibiæ, and tarsi beneath (the apices of the segments of the tarsi are ringed with black), the apical half of the middle femora beneath, the middle tibiæ beneath, a ring on the middle of the posterior tibiæ, the middle and posterior tarsi except the apices of the segments, and two spots on the apex of the basal plates at middle ; the clypeus broadly and roundly emarginate; the third segment of the antennæ twice the length of the fourth; the wings slightly infuscated; the veins, including the costa and stigma, black. Length, ro $\mathrm{mm}$.

Habitat - Plattsburg, New York. Mr. H. G. Dyar, collector 
This species is related to lineata, from which it is separated by the colour of the posterior femora.

Macrophya minuta, n. sp. o.- Black, with the following parts white: the labrum, the mandibles except at apex, the outer margins of the tegulæ, the cenchri, the front and middle coxæ at apex, the posterior coxæ at apex and an ovate spot at side, the trochanters, the front and middle femora and tibix beneath, the front and middle tarsi except fuscous rings on the apices of the segments, and a narrow ring on the base of the posterior femora; the clypeus broadly emarginate; the labrum angularly emarginate; the head and thorax coarsely punctate; the third segments of the antennæ about one-fourth longer than the fourth; the wings hyaline; the veins black; the stigma, except its front margin, blackish-rufous; the lanceolate cell contracted at middle. Length, $6.5 \mathrm{~mm}$.

Habitat-Plattsburg, New York. Mr. H. G. Dyar, collector.

\section{OENECTRA FLAVIBASANA, FERN.}

On the 2 oth of June, I $895, \mathrm{Mr}$. Balkwill brought to me some Tortricid moths which he found at rest upon honeysuckle in his garden. They were new to me. He asked if I wanted any more? I said I would take all he liked to bring of that kind; so by the 27 th I had got about three dozen of them. Being desirous of learning something about them, I applied to Prof. C. H. Fernald for information, and sent some of the moths. He replied: "They are Oenectra flavibasana; Fern. That he had two specimens in his collection; the types: one from Texas and one from Illinois. That nothing is known of their early stages or food plants, and would be glad to have published all that was known on these points." Up to the present time I can give nothing with certainty upon these points. Presumably, the larvæ had fed upon the honeysuckle, as chrysalids were found in the connate leaves with a thin silken web spun over them, one of which I raised to the moth. There is plenty of evidence of feeding having been done upon the plant, but nothing positive as to what did it. A lookout is being kept upon the plants for the next brood.

The original description was published in the Transactions of the American Entomological Society, Vol. X., p. 69, I882. I see by it that the types are females. I may mention that the males are decidedly smaller in size, and lighter in colour, as a rule; otherwise the sexes do not perceptibly differ.

J. Alston Moffat, London, Ont. 